\title{
EFFECT OF USING MYCOTOXINS DEACTIVATOR WITH NATURALLY MYCOTOXINS CONTAMINATED OR NOT CONTAMINATED CORN SILAGE ON LACTATING COWS PERFORMANCE
}

\author{
N.E. El-Bordeny ${ }^{1}$ and M.S. El-Garhi ${ }^{2}$ \\ Animal production department, Faculty of Agriculture,Ain Shams University, Cairo, Egypt. \\ Animal Reproduction Research Institute, Agricultural Research Center, Giza, Egypt.
}

(Received 1/10/2015, Accepted 29/11/2015)

\section{SUMMARY}

$\mathrm{M}$ ycotoxins especially aflatoxin $\mathrm{B}_{1}$ and zearalenonecausea wide range of harmful effects in farm animals. The problems of mycotoxins are not only just end in the harmful effect on animal performance but also many of them become concentrated in milk and can pose a threat to human health. So, this study aimed to investigate the effect of using mycotoxin deactivator inlactating animal ration to reducing the harmful effect of micotoxins on animal performance and milk safety. A total of twentyfour primiparous and multiparous Holstein lactating cows were assigned to two groups of twelve cows each. The experiment was extended for one month and the animals were fed total mixed ration (TMR) in quantities suffusion to provide about $10 \%$ in excess of the expected daily intake for ad libitum consumption. The control group was fed TMR containing about $10 \%$ high microbiologically quality corn silage (normal silage) + mycotoxindeactivator (MD) product, while the second group was fed TMR containing about $10 \%$ low microbiologically quality corn silage (naturally contaminated with mycotoxins) + MD product. A significantly $(\mathrm{P}<0.05)$ reduction in ruminal viable total bacteria and cellulytic bacteria count were observed in the group fed mycotoxin contaminated silage compared to the control group. Acetate and propionate concentration were significantly $(\mathrm{P}<0.05)$ lower in ruminal fluid of the cows fed mycotoxin contaminated silage than those in control group. Feeding mycotoxin contaminated silage significantly $(\mathrm{P}<0.05)$ decreased DM, CF, NFC and ADF digestibility compared to control group. While insignificant $(\mathrm{P}>0.05)$ differences were observed in digestibility of OM, CP, EE and NDF. No significant effect on the concentration of total protein, globulin, A/G ratio, bilirubin concentration and ALT and AST activity. Cows fed contaminated corn silage showed a decrease in the averagefeed intake andmilk production. Feeding contaminated corn silage resulted inincreased aflatoxin $M_{1}$ in milk. These results support that the hygienic quality of silage is more important than using mycotoxins deactivator for animal performance, even with using low percent of contaminated feed and maintain the level of total aflatoxin and aflatoxin $\mathrm{B}_{1}$ concentration lower than the permissible limits.

Keywords: nutrientsdigestibility, performance, rumen ecology, VFA concentration, milk safety.

\section{INTRODUCTION}

Consumption of mycotoxin contaminated feeds induce: reduced feed intake, feed refusal, poor feed conversion, diminished body weight gain, increased disease incidence (due to immune-suppression), and reduced reproductive capacities (Fink-Gremmels and Malekinejad, 2007 and Whitlow and Hagler(2005) which leads to economic losses $(\mathrm{Wu}, 2006)$. Aflatoxine $\mathrm{B}_{1}\left(\mathrm{AFB}_{1}\right)$ reduced cellulose breakdown and production of VFAs and $\mathrm{NH}_{3}$ both in in vivo and in vitro rumen model systems (Mertens and Wyatt, 1977).

The problems of mycotoxinsare not only just end in reducedanimal feed andreduceanimal performancebut also manyof thembecome concentrated in meat, egg and milk as an animal productand can pose a threat to human health, which explains the major concern of food and feed industries in preventing them from entering the food chain (Akandeet al., 2006).

The hygienic quality of silage is important for animal health, animal production and food quality and safety. Silages with poor aerobic stability can be found on many farms because of slow filling rates or inadequate packing densities at the time of ensiling. In addition, removal of inadequate amounts of silage during feedout and poor management at the face of the silo exposes the silage mass to prolonged contact 
with air. Consequently, lactate-assimilating yeasts (e.g., Candida, Endomycopsis, Hansenula, and Pichia; Woolford, 1990) degrade lactic acid to carbon dioxide and water and produce excessive heat that leads to a loss of nutrients. Degradation of lactic acid also increases the $\mathrm{pH}$ of the silage to a level that allows opportunistic bacteria (e.g., Bacilli; McDonald et al., 1991) and molds (e.g., Aspergillus, Fusarium, and Penicillium; McDonald et al., 1991) to grow and further reduce silage quality and possibly also the formation of toxic metabolic products by moulds (mycotoxins) significantly affect the quality of the silage, possibly even to the extent that it becomes unfit for use as feed.

It is very important to control the total ration mycotoxins through modern detoxification methods, based on the utilization of dietary supplements such as absorptive materials that can bind the most types of mycotoxins(yeast cell walls, clays and charcoal, etc.). Yeast cell walls constituents such as mannan oligosaccharides (MOS) and beta-glucan have shown the ability to bind aflatoxins (Zaghiniet al., 2005) and zearalenone(ZEA;Yiannikouriset al., 2004), respectively. Clays have shown the ability to bind ZEA (Sabater-Vilaret al., 2007) but have no affinity for trichothecenes (Sabater-Vilaret al., 2007). Absorptive agents have been the object of many studies. Hydrated sodium aluminosilicates (HSCAS) have shown a high affinity for aflatoxin $\mathrm{B}_{1}$ and the ability to reduce its growth inhibitory effects in chicks (Phillips et al., 1988). In a study with piglets fed diets contaminated with aflatoxins, different clays (including zeolite, sepiolite, and bentonite) improved animal performance (Schell et al., 1993).

So, the objective of the current study was to investigate effect of adding mycotoxindeactivatortolactating cows rations with mycotoxins contaminated or not contaminated corn silage on feed intake, rumen ecology, digestibility, blood metabolites and productive performance.

\section{MATERIALS AND METHODS}

This study was conducted at private farm,Benisuef, Egypt, Animal Reproduction Research Institute, Agricultural Research Center and Research Laboratories of Animal Nutrition, Department of Animal Production, Faculty of Agriculture, AinShams University.

\section{Mycotoxins deactivator:}

The mycotoxins deactivator(MD) contained anti-fungal agents and liver activator such as sorbic acid $0.05 \%$, citric acid $0.75 \%$, calcium propionate $10.5 \%$, copper sulphate $5 \%$ andinactivated yeast (Saccharomyces Cerevisiae) $2 \%$ as a source of yeast cell walls and sepiolite $41.7 \%$, bentonite $40 \%$ as toxin adsorbent agent. The MD was added to the ration of the two groups as feed additive.

\section{Animalsmanagement and experimental design:}

Twenty-four primiparous and multiparous Holstein lactating cows $(620 \mathrm{Kg}$ average body weight, $32 \mathrm{~kg}$ average daily milk yield and 126 average days in milk(DIM)) were assigned to two groups of twelve cows each, according toproductivity, DIM andlactation season, the animals were each randomly allocated to one of the two dietary treatments. The experiment was extended for one month and the animals were fed total mixed ration (TMR, Table 1) in quantities to provide about $10 \%$ in excess of the expected daily intake for ad libitum consumption. The control group was fed TMR containing about $10 \%$ high microbiologically quality corn silage + MDproduct, while the second group was fed TMR containing about $10 \%$ low microbiologically quality corn silage (naturally contaminated with mycotoxins)+ MDproduct. Each group was placed in a shaded pen equipped with free stalls. The diets wereformulated to cover NRC requirement for dairy cattle (NRC, 2001).Cows were fed as a group with free access to water.Feed intake and feed refusals were recorded daily for each group and DM intake was calculated.

\section{Sampling and analytical methods:}

\section{Feed and fecal samples:}

Samples of corn silages and TMRs were collected weekly and composed to get one sample from each feedstuff. Feed samples and fecal matter samples were dried at $60^{\circ} \mathrm{C}$ for $48 \mathrm{~h}$ then ground to pass a $1 \mathrm{~mm}$ screen in a Wiley mill before analyzed. Samples of TMR were analyzed for dry matter (DM), organic matter (OM), crude fiber (CF), ether extract (EE) and crude protein (CP) according to AOAC, (2000). The NDF and ADF were determined according to Van Soestet al. (1991). Non-fiber carbohydrate (NFC) was calculated according to the following equation:

$\mathrm{NFC} \%=100-(\% \mathrm{NDF}+\% \mathrm{CP}+\%$ fat $+\%$ ash $)$ according to NRC (2001). 
Table (1). Formulation and chemical composition of the experimental total mixed ration.

\begin{tabular}{|c|c|c|}
\hline \multicolumn{3}{|l|}{ Ingredient } \\
\hline Total mixed ration formulation, $\%$ as fed & Control TMR $* * *$ & Contaminated TMR \\
\hline Egyptian clover (Berseem & 71.43 & 71.43 \\
\hline Non contaminated corn silage & 10.71 & 0 \\
\hline Contaminated corn silage & 0 & 10.71 \\
\hline Yellow corn grain, ground, dry & 7.77 & 7.77 \\
\hline Cotton seed cake & 2.68 & 2.68 \\
\hline Soybean meal $44 \%$ & 5.09 & 5.09 \\
\hline Wheat bran & 1.81 & 1.81 \\
\hline Lime stone & 0.11 & 0.11 \\
\hline Salt & 0.11 & 0.11 \\
\hline Premix * & 0.05 & 0.05 \\
\hline Detoxification agent & 0.04 & 0.04 \\
\hline Sodium bicarbonate & 0.2 & 0.2 \\
\hline \multicolumn{3}{|l|}{ Chemical composition (g/kg DM) } \\
\hline Organic matter $(\mathrm{OM})$ & 880.10 & 875.06 \\
\hline Crude protein & 170.53 & 170.21 \\
\hline Ether extract (EE) & 69.37 & 70.87 \\
\hline Non fiber carbohydrate (NFC) & 310.43 & 292.50 \\
\hline Neutral detergent fiber (NDF) & 329.78 & 341.47 \\
\hline Acid detergent fiber (ADF) & 199.93 & 210.05 \\
\hline $\mathrm{NE}_{\mathrm{L}}(\mathrm{Mcal} / \mathrm{kgDM})^{* *}$ & 1.57 & 1.57 \\
\hline
\end{tabular}

Table (2).Mycotoxins contents of normal and contaminated corn silage as well as the experimental total mixed rations

\begin{tabular}{lcccc}
\hline Ingredient & $\begin{array}{c}\text { Control } \\
\text { TMR }\end{array}$ & $\begin{array}{c}\text { Contaminated } \\
\text { TMR }\end{array}$ & normal silage & $\begin{array}{c}\text { contaminated } \\
\text { silage }\end{array}$ \\
\hline Mycotoxins concentrations $\mu \mathrm{g} / \mathrm{kg} \mathrm{DM}:$ & & & & \\
Total mycotoxins & 2.76 & 5.05 & 14.83 & 39.71 \\
Aflatoxin $\mathrm{B}_{1}\left(\mathrm{AFB}_{1}\right)$ & 1.85 & 1.98 & 4.9 & 6.3 \\
Zearalenone & 131.79 & 142.27 & 195 & 309 \\
Ochratoxin & 5.84 & 6.40 & 11.2 & 17.21 \\
\hline
\end{tabular}

Feed samples were subjected to analyze the presence of the most important mycotoxins affecting animal performance and health, namely, total aflatoxin, aflatoxinB $B_{1}$,zearalenone, ochratoxin using ELIZA according to Berthilleret al.(2007).

\section{Milk sampling and analysis:}

Cows were milked three times daily at $4 \mathrm{am}, 12 \mathrm{pm}$. and $8 \mathrm{pm}$ using De-laval milk manager model Sortie. Milk yield for all cows were determined daily, milk samples were obtained once every weeks from each cow for the three consecutive milking and pooled within cow relative to production to obtain one composite milk sample per animal and stored at $+4{ }^{\circ} \mathrm{C}$ until subjected to chemical analyses. Milk samples were analyzed for total solids, fat, true protein, solid-not-fat, lactose and milk-urea N (MUN) by infrared spectrophotometry (Milko-Scan, FT 6000). While somatic cell counts (SCC) was analyzed using the Fossomatic 5000. Aflatoxin $\mathrm{M}_{1}\left(\mathrm{AFM}_{1}\right)$ was determined using ELIZA according tomethods of Berthilleret al. (2007). Fat corrected milk (4\% fat) was calculated according to equation of Gaines (1928).

$$
4 \% \mathrm{FCM}=0.4 \text { milk yield }(\mathrm{g})+15 \text { fat yield }(\mathrm{g})
$$




\section{Blood sampling and analysis:}

At the end of experimental period, blood samples were taken from the coccygeal vasculature using the vacutainer system from 10 experimental animals of each group. The blood sample was collected in a clean centrifuge tube,the blood serum was obtained by centrifuging the blood samples $2 \mathrm{~h}$ after collection at $3500(\mathrm{rpm})$ for 20 minutes. Blood serum was transferred into a clean dried glass vials and then stored in deep freezer at $-20^{\circ} \mathrm{C}$ for subsequent specific chemical analysis. Blood serum samples were analyzed using commercial kits. Total serum protein concentrations was determined as described by Weichselbaun (1946), albumin concentrations was determined using methods of Dumas and Biggs (1972)and activity of serum alanintransaminas (ALT) and aspartate transaminas (AST) were determined using ALT and AST kits, respectively based on reaction of Reitman \& Frankel (1957).Globulin was calculated by subtraction of total serum protein and serum albumin, while AG ratio was calculated by dividing the value of albumin on the value of globulin in serum.

\section{Rumen liquor sampling and analysis:}

At the end of the experiment, rumen liquor samples (about $200 \mathrm{ml}$ ) were taken $4 \mathrm{~h}$ after morning feeding, from 10 and 8 cows for control and contaminated group using stomach tube connected with a vacuum pump. Samples of rumen liquor were strained through three layers of cheesecloth. Ten $\mathrm{ml}$ of strained rumen liquor samples were immediately transferred to the laboratory and the most probable number calculations were used to estimate the numbers of total viable bacterial count and cellulolytic bacterial count in rumen fluid on nutrient broth and cellulose broth medium, respectively (Nikki etal., 2011). The remaining strained samples were acidified with $5 \mathrm{ml}$ of $2 \mathrm{~N}$ sulphuric acid $\left(\mathrm{H}_{2} \mathrm{SO}_{4}\right)$ to stop microbial activity. The samples were then centrifugated at $3000 \mathrm{rpm}$ for $10 \mathrm{~min}$ and the supernatant (100 $\mathrm{mL}$ ) was taken. The supernatant was kept in aplastic bottle where $5 \mathrm{~mL}$ of $1 \mathrm{M} \mathrm{H}_{2} \mathrm{SO}_{4}$ was added and frozen at $-20{ }^{\circ} \mathrm{C}$ for VFAs analyses. Ruminal liquor samples were analyzed for VFAs by using spectrophotometer, according tothe method of Siedlkaet al. (2008).

\section{Digestibility trial:}

Acid insoluble ash (AIA) was used as an internal marker for determining the digestibility (Van Keulen and Young 1977). Fourh after the morning feeding, fecal samples were collected for three consecutive days from rectum of each cow. The feces of each cow were mixed thoroughly, and a subsample (500 g) was dried at $60^{\circ} \mathrm{C}$ in a forced air oven for $48 \mathrm{~h}$. Dry samples were ground witha Wiley mill ( $2 \mathrm{~mm}$ screen). Dry matter excreted in feces was calculated by dividing AIA input in the feeds (grams of AIA/ day) by AIA output in the feces (grams of AIA/ day). The digestibility coefficient of certain nutrients was calculated according to the formula of Van Keulen and Young (1977):

$$
\text { Digestibility }=100-\left[100 \times \frac{\% \text { indicatorin feed }}{\% \text { indicatorin feces }} \times \frac{\% \text { nutrientin feces }}{\% \text { nutrientin feed }}\right]
$$

\section{Statistical analyses:}

The obtained data were statistically analyzedusing ANOVA procedure for a complete randomized designaccording to statistical analysis system (COSTAT) according to Snedecor and Cochran (1982).Repeated-measures data over time and within animal wereaveraged before analysis. Separation between means was carried out by using Duncan Multiple Range Test (Duncan, 1955).Differences are deemed significant when $P \leq 0.05$. The full model tested was:

$$
Y_{i j}=\mu+T_{i}+e_{i j} \text {, }
$$

Where $y_{i j}=$ represents observation, $\mu=$ : the overall mean, $T_{i}=$ effect of treatment (experimental group), $\mathrm{e}_{\mathrm{ij}}$ : experimental error.

\section{RESULTS AND DISCUSSION}

\section{Chemical compositionof the experimental rations and mycotoxinsconcentrations:}

The chemical composition of the feed ingredients used in this study is presented in Table (1). The data indicated that both groups were fed on the same formula with replacing the normal corn silage with the contaminated corn silage in contaminated TMR and the slightly differences in the chemical composition may be due to the differences in corn silages chemical composition. The data indicated that total mixed ration nutrientscontents for both groupswere met cows with nutrient requirements according to 
NRC(2001).The data of Table (2) indicated that contaminatedcorn silage which fed to the mycotoxins infected groupcontains a high level of total aflatoxin andaflatoxin $\mathrm{B}_{1}$, which exceed the permissible limits 20 and $5 \mu \mathrm{g} / \mathrm{kg} \mathrm{DM}$, respectively, as well as contain 58.5 and $53.8 \%$ more zearalenoneand ochratoxin compared to the non-contaminated corn silage which fed to the control group. While the values oftotal aflatoxin andaflatoxin $B_{1}$ contents in TMR for both experimental treatmentswere not exceeded the permissible limits. The Food and Drug Administration(FDA) has established no guidelines for zearalenone andochratoxin in feed, so any contamination issue is dealt with on a case-by-case basis (Henry, 2006).

\section{Populations of ruminal microorganisms and VFA concentrations:}

Rumen activity, total bacteria count and cellulytic bacteria count are presented in Table (3). Although, the mycotoxin deactivator used in this study contains a mixture of antifungal agents and toxin adsorbent agents as well as the total aflatoxin and aflatoxin $\mathrm{B}_{1}$ contents in TMR for both experimental rationswere not exceeded the permissible limits, a significantly $(\mathrm{P}<0.05)$ reduction in ruminal viable total bacteria and cellulytic bacteria count were observed in the groupfed mycotoxincontaminated silage compared to the control group, which estimated by about 10.77 and $28.57 \%$, respectively. It could be observed that cellulytic bacteria are the most affected populations in rumen bacteria. These results could be due to the toxic effect of mycotoxins on rumen bacteria.May et al. (2000)observed that presence of vomitoxin, deoxynivalenolorfusaricacid separately or together caused a depression in Methanobrevibacterruminantiummicrobialactivity.

Total volatile fatty acid concentrations are shown in Table (3). The data revealed that ruminal acetate and propionate concentration were significantly $(\mathrm{P}<0.05)$ lower in ruminal fluid of the cows fedmycotoxincontaminated silage than those in control group.Also, butyrate concentration tend to be significantly $(\mathrm{P}=0.056)$ higher in control group compared totreated group. It could be attributed to the negative effect of mycotoxin on total rumen bacteria and cellulyticbacteria counts in this study (Table 2) which depress rumen fermentation activity consequently, decrease VFA's concentration and or the lower capability of MD to decrease the effect of mycotoxins on fermentation. In this connection Tabiaet al. (2005)foundin in vitro study thatacetate concentration was depressed $(P<0.05)$ withpatulin(mycotoxin)addition due to a reduction in fiber digestion. Conversely, there was a shift in fermentation with buterate and valerate concentration, which increased significantly with adding patulin. Also Cook et al., (1986)andDiekman and Green, (1992)reported that presents aflatoxin in feed have been induce compromise ruminal function by reducing cellulose digestion, volatile fatty acids (i.e. acetate, propionate and butyrate) production and rumen motility.

Table (3). Effect of experimental treatments on rumen populations andvolatile fatty acids concentrations.

\begin{tabular}{lccc}
\hline Item & $\begin{array}{c}\text { Control } \\
\text { TMR }\end{array}$ & $\begin{array}{c}\text { Contaminated } \\
\text { TMR }\end{array}$ & P-value \\
\hline Number of animal $(\mathrm{N})$ & 10 & 8 & \\
Total bacterial count $\left(\mathrm{cfu} \times 10^{8} / \mathrm{ml}\right)$ & $28.5 \pm 0.27^{\mathrm{a}}$ & $25.43 \pm 0.3^{\mathrm{b}}$ & 0.053 \\
Cellulolytic bacterial count $\left(\mathrm{cfu} \times 10^{6} / \mathrm{ml}\right)$ & $4.9 \pm 0.05^{\mathrm{a}}$ & $3.5 \pm 0.08^{\mathrm{b}}$ & 0.0016 \\
Volatile fatty acids concentration & & & \\
Acetic, $\mathrm{mm} / \mathrm{ml}$ & $26 \pm 0.32^{\mathrm{a}}$ & $21.73 \pm 0.5^{\mathrm{b}}$ & 0.0473 \\
Propionic, $\mathrm{mm} / \mathrm{ml}$ & $11.146 \pm 0.27^{\mathrm{a}}$ & $7.56 \pm 0.16^{\mathrm{b}}$ & 0.0081 \\
Acetate/propionate ratio & 2.33 & 2.87 & \\
Butyric, $\mathrm{mm} / \mathrm{ml}$ & $5.093 \pm 0.17^{\mathrm{a}}$ & $3.616 \pm 0.09^{\mathrm{b}}$ & 0.0565 \\
\hline
\end{tabular}

Values in a row followed by a different superscripts are significantly different $(P<0.05)$.

The observed adverse effect on rumen population and fermentation parameters in this study may be pointed to that the mycotoxin deactivator had no the capability to totally stop the harmful effect of mycotoxinsin contaminated corn silage. This result could be attributed to that the antifungal agent had no effect on mycotoxins in the rumen and or the lower present of MD in the total ration $(0.04 \%)$. In this connection, several experiments reported that inorganic adsorbing agents were able to decrease the harmful effect of mycotoxins in ruminant ration when used at high percent, which Kutzet al. (2009) usedHSCAS at 0.56\%;Galvanoet al., 
(2001) used HSCAS at 2\%; Smith et al. (1994)usedbentonite by 2 and 4\%and Diaz et al., (2004) used sodium-bentonite at $1.2 \%$.

\section{Nutrients digestibility:}

The data of Table (4) showed the effect of experimental diets on nutrients digestibility coefficients.Despite mycotoxins deactivator compounds was added for both experimental treatments and the total aflatoxin and aflatoxin $B_{1}$ contents of both experimental rationswere not exceeded the permissible limits.Feeding mycotoxin contaminated silage showed significant $(\mathrm{P}<0.05)$ decrease forDM, $\mathrm{CF}, \mathrm{NFC}$ and ADF digestibility compared to feeding non-contaminated silage (control group), while insignificant $(\mathrm{P}>0.05)$ differences were observed in digestibility of $\mathrm{OM}, \mathrm{CP}, \mathrm{EE}$ and NDF as well as the feeding values as digestible crude protein ant total digestible nutrientsbetween the two experimental groups.

Table (4). Effect of experimental treatments on nutrients digestibility, \%.

\begin{tabular}{lccc}
\hline Item & $\begin{array}{c}\text { Control } \\
\text { TMR }\end{array}$ & $\begin{array}{c}\text { Contaminated } \\
\text { TMR }\end{array}$ & p-value \\
\hline Number of animal (N) & 10 & 8 & \\
Dry matter, \% & $57.54^{\mathrm{a}}$ & $54.99^{\mathrm{b}}$ & $<0.001$ \\
Organic matter, \% & $58.589 \pm 0.02$ & $58.09 \pm 0.03$ & 0.66 \\
Crude fiber, \% & $63.11 \pm 0.04^{\mathrm{a}}$ & $54.21 \pm 0.08^{\mathrm{b}}$ & 0.003 \\
Crude protein , \% & $66.053 \pm 0.08$ & $66.11 \pm 0.02$ & 0.95 \\
Ether extract, \% & $84.71 \pm 0.04$ & $84.89 \pm 0.03$ & 0.91 \\
Non fiber carbohydrate, \% & $48.40 \pm 0.06^{\mathrm{b}}$ & $53.62 \pm 0.04^{\mathrm{a}}$ & 0.045 \\
Neutral detergent fiber, \% & $49.17 \pm 0.02$ & $47.57 \pm 0.05$ & 0.31 \\
Acid detergent fiber, \% & $47.10 \pm 0.05^{\mathrm{a}}$ & $40.75 \pm 0.07^{\mathrm{b}}$ & 0.025 \\
Nutritive Value: & & & \\
Digestible crude protein (DCP) & $11.24 \pm 0.10$ & $11.27 \pm 0.11$ & 0.994 \\
Total digestible nutrients (TDN) & $58.98 \pm 0.65$ & $58.24 \pm 0.72$ & 0.774 \\
\hline
\end{tabular}

Values in a row followed by a different superscripts are significantly different $(P<0.05)$.

The great reduction in crude fiber and ADF degradation, 14.10 and $13.48 \%$ respectively in the mycotoxin affected group compared to the control group could be attributed to the great reduction in total rumen bacteria especially cellulytic bacteria count in the present study (Table 3). The results of Tapia et al. (2005) support our results which found that digestion of organic matter, acid detergent fiber, non-fiber carbohydrate and crude protein was reduced $(P<0$.05)withpatulinaddition. Also, Westlake et al. (1989) and Mojtahedi (2013) observed that in vitro DM degradability (IVDMD) and total gas production were decreased significantly with inclusion of $\mathrm{AFB}_{1}$ in culture medium. While Auerbachet al. (1998) reported a rumen $\mathrm{AFB}_{1}$ content of $9.5 \mu \mathrm{g} / \mathrm{ml}$ did not modify in vitro digestion of alfalfa and VFAs productions. The reasons for this might be the low mycotoxin concentrations in the inoculums media, or high-quality environmental conditions at the research facility, which could result in unpredictable effects.

\section{Blood metabolites:}

The effect of feeding ration contaminated with mycotoxins on blood metabolites are presented in Table (5). The data indicated that adding mycotoxins deactivator to the ration of animals fed contaminated corn silage success to some extent to dilute the harmful effect of mycotoxins on some blood metabolites which, there is no significant effect on the concentration of total protein, globulinandA/G ratioas well as non significant increase in ALT and AST activity for group fed contaminated corn silage compared to control group. Although, the observed insignificant results in blood metabolites in this study, the data may be pointed to that the animal fed rations not contaminated recorded for optimum ALT and AST activity compared to the animals fed ration contained contaminated corn silage. These results are in agreement with Bingolet al. (2007)who reported that no correlation was found between feeding contaminated feed with aflatoxinand AST activity when studied the influence of aflatoxin levels in forages and concentrate feedstuffs on some serum parameters in goats. On the contrary, negative correlations were observed between feed total aflatoxin content and total proteins, albumin, globulin concentrations, and ALT activities (Bingolet al., 2007).The results of Bingolet al. (2007) suggest that there was no liver damage to the goats when consuming 82 to $820 \mu \mathrm{gAFB} / \mathrm{kg}$ of the diet.While,Applebaumet al. (1982) reported higher blood levels of bilirubin andASTin dairy cows consuming contaminated feeds. In addition, dairy cows exhibited decreased milk production, liver 
damage and lethargy (Neatheryet al., 1980), this inconsistency between results were may be due to differences in animal species, animal ration, physiological status, milk production and types of mycotoxins.

On the other hand,the data indicated that albumin concentration was significantly $\operatorname{lower}(\mathrm{P}<0.05)$ in cows fed contaminated corn silage compared to the control group, meanwhile that the control group was in best metabolism status compared to the group fed contaminated silage. This result could be due to that the control group recorded higher DM digestibility (Table 4), which led to more available nutrients for absorption.

Table(5).Effect of experimental treatments on some blood metabolites.

\begin{tabular}{|c|c|c|c|}
\hline Item & $\begin{array}{c}\text { Control } \\
\text { TMR }\end{array}$ & $\begin{array}{c}\text { Contaminated } \\
\text { TMR }\end{array}$ & P-value \\
\hline Number of animal (N) & 10 & 8 & \\
\hline Total protein, $\mathrm{g} \mathrm{dl}^{-1}$ & $6.16 \pm 0.09$ & $6.18 \pm 0.09$ & 0.96 \\
\hline Albumin, $\mathrm{g} \mathrm{dl}^{-1}$ & $3.59 \pm 0.07^{\mathrm{a}}$ & $2.95 \pm 0.07^{\mathrm{b}}$ & 0.05 \\
\hline Globulin, $\mathrm{g} \mathrm{dl}^{-1}$ & $2.56 \pm 0.11$ & $3.23 \pm 0.08$ & 0.18 \\
\hline $\mathrm{A} / \mathrm{G}$ ratio & $2.11 \pm 0.15$ & $0.99 \pm 0.03$ & 0.06 \\
\hline AST, unit $\mathrm{l}^{-1}$ & $110 \pm 6$ & $80 \pm 6$ & 0.28 \\
\hline ALT, unit $1^{-1}$ & $37 \pm 2$ & $85 \pm 8$ & 0.08 \\
\hline
\end{tabular}

Values in a row followed by a different superscripts are significantly different $(P<0.05)$.

\section{Feed intake and milk production and composition:}

Data of Table (6)showed that although the total aflatoxin and aflatoxin $\mathrm{B}_{1}$ were not exceeded the permissible limits for both rations, feeding contaminated corn silage with using MD significantly decreased $(\mathrm{P}<0.05)$ dry matter intake. This may be attributed to effect of mycotoxin on digestibility which the cows fed contaminated corn silage recorded the lowest DM and CF digestibility (Table 4) compared to control group.The present results are in agreement with findings of Whitlow and Hagler (2008), who observed that feeding dairy cows with contaminated feeds resulted in reducing feed consumption. On the contrary Kutzet al. (2009)found that no effects on DMI or milk yield whencontaminated TMR with $\mathrm{AFB}_{1}$ was fed to dairy cows.

Also, the data indicated that feeding contaminated corn silage even with using MDsignificantly $(\mathrm{P}<0.05)$ reduced milk production compared to the control group. The higher milk production of cows in the control group in the present study may be supported with that the control group recorded for higher rumen activity (Table 3), higher nutrients digestibility (Table 4), higher albumin concentration (Table 5) and higherfeed intake (Table 6) which was assumed to supply more nutrients than the group fed corn silage contaminated with mycotoxins.

The present results are in agreement withWhitlow and Hagler (2008)who reported that mycotoxins affect dairy cows by reducing milk production. On the contraryKorostelevaet al. (2007) observed that feeding a TMR naturally contaminated with mycotoxins to lactating cows did not reduce milk production. This inconsistency may be due to types and levels of mycotoxinscontamination, ration formula and cow physiological status.

Concerning to milk chemical composition the data of Table (6)indicated that milk lactose was significantly decreased in group fed contaminated corn silage compared to control group. While, there was no significant differences between the two groups in milk protein, fat,total solids and milk urea contentsas well as somatic cell count. Smith et al. (1994) found insignificant effect in milk protein and fat percentages due to feeding diet contaminated with $\mathrm{AFB}_{1}$ to goats. Also Kutzet al. (2009) reported that milk protein and fat percentage were unaffected when dairy cows were fed an aflatoxin contaminated diet.

Concerning effect of experimental treatment on feed conversion, the data of Table (6) indicated that the animal of the control group recorded the best feed conversion as $\mathrm{kg}$ DM per $\mathrm{kg}$ milk and $\mathrm{kg}$ DM per $\mathrm{kg}$ FCM 4\% compared to the group fed contaminated corn silage. These results could be attributed to that the control group recorded the higher DM digestibility and higher feed intake as well as the higher milk and FCM yield compared to the group fed contaminated corn silage. 


\section{Milk safety:}

To avoid the risk of aflatoxin ingestion and intoxication, agencies around the world have established acceptable limits for aflatoxin concentration in milk and feeds. In the United States, the FDA stipulated action levels for aflatoxin in raw milk and lactating cow feeds are $0.5 \mu \mathrm{g} / \mathrm{L}$ and $20 \mu \mathrm{g} / \mathrm{kg}$, respectively (FDA, 2000). The maximum allowable concentration set by the European Commission is $0.05 \mu \mathrm{g} / \mathrm{L}$ of milk (EFSA, 2004).

The results of Aflatoxin M1 concentration, $\mu \mathrm{g} \mathrm{kg}{ }^{-1}$ during the experimental period are presented in Table (6). The dataindicated that aflatoxin $\mathrm{M}_{1}$ concentration in milk of the group fed contaminated corn silage was higher than those in milk of control group during all of the experimental periods (4 weeks). Moreover, the present results indicated thataflatoxin $\mathrm{M}_{1}$ transfer rate to milk ranged between 1.62 to $2.97 \%$ for the control group, while ranged from 14.14 to $18.18 \%$ for the group fed contaminated corn silage. These mean that micotoxins deactivator could not decrease transfer rate under feeding contaminated feed. In this connection, Veldmanet al. (1992) found that $\mathrm{AFB}_{1}$ in the feed materialswastransferred to milk as $\mathrm{AFM}_{1}$ ranged from $0.8-2 \%$ of the total aflatoxinconcentration in dry matter, butcan be as high as $6 \%$ in highproducing cows. Also, Stroud (2006) reported that $50 \mu \mathrm{gg}^{-1}$ of $\mathrm{AFB}_{1}$ concentrations in cows feed is sufficient to exceed the FDA action limit of $0.5 \mu \mathrm{g} / \mathrm{L} \mathrm{AFM} \mathrm{Am} \mathrm{milk}$, assuming transfer of $1.0 \%$ into milk. Maximum levels of AF in milkregulated in many countries, which the maximum level estimated with $0.05 \mu \mathrm{g} \mathrm{kg}^{-1}$ in EU standard and $0.5 \mu \mathrm{g} \mathrm{kg}^{-1}$ in USA according to FDA regulation. It is obvious that the $\mathrm{AFM}_{1}$ concentration in the milk of control group met the European standard $\left(0.05 \mu \mathrm{g} / \mathrm{kg}\right.$ milk) while the concentration of $\mathrm{AFM}_{1}$ in milk of the group fed contaminated corn silage was very high which exceeded from 6-12 times the concentration in milk of control group.

Table (6). Effect of experimental treatmentson DMI, average milk production, milk constituentsandaflatoxin $M_{1}$ in milk.

\begin{tabular}{|c|c|c|c|}
\hline Item & $\begin{array}{l}\text { Control } \\
\text { TMR }\end{array}$ & $\begin{array}{l}\text { Contaminated } \\
\text { TMR }\end{array}$ & p-value \\
\hline Number of animal (N) & 12 & 12 & \\
\hline DMI, $\mathrm{kg} \mathrm{h}^{-1} \mathrm{~d}^{-1}$ & $23.9 \pm 0.03^{\mathrm{a}}$ & $20.6 \pm 0.21^{b}$ & 0.042 \\
\hline Milk yield, $\mathrm{kgh}^{-1} \mathrm{~d}^{-1}$ & $31.57 \pm 0.28^{\mathrm{a}}$ & $24.73 \pm 0.18^{\mathrm{b}}$ & 0.0001 \\
\hline Fat corrected milk yield, $\mathrm{kg} \mathrm{h}^{-1} \mathrm{~d}^{-1}$ & 30.244 & 22.84 & 0.0001 \\
\hline Milk fat, \% & $3.72 \pm 0.09$ & $3.49 \pm 0.06$ & 0.55 \\
\hline Milk protein, $\%$ & $2.94 \pm 0.03$ & $2.81 \pm 0.03$ & 0.39 \\
\hline Milk lactose, $\%$ & $4.07 \pm 0.04^{\mathrm{a}}$ & $3.70 \pm 0.03^{b}$ & 0.045 \\
\hline Milk total solids, $\%$ & $10.74 \pm 0.08$ & $10.81 \pm 0.07$ & 0.85 \\
\hline Milk urea, $\mathrm{mg} \mathrm{kg}^{-1}$ & $19.28 \pm 0.67$ & $25.625 \pm 0.61$ & 0.056 \\
\hline Somatic cell count $\left(\mathrm{X} 10^{3}\right.$ cells $\left./ \mathrm{mL}\right)$ & $101.833 \pm 8.46$ & $154.667 \pm 10.44$ & 0.27 \\
\hline \multicolumn{4}{|l|}{ Feed conversion ratio, $\mathrm{kg} / \mathrm{kg}$ milk } \\
\hline Kg DMI/ kg milk & 0.76 & 0.83 & \\
\hline Kg DMI/ kg FCM & 0.79 & 0.90 & \\
\hline \multicolumn{4}{|c|}{ Aflatoxin $\mathrm{M} 1$ concentration in the milk, $\mu \mathrm{g} \mathrm{kg}^{-1}$} \\
\hline $1^{\text {st }}$ week AFM $1^{1}, \mu \mathrm{g} \mathrm{kg}^{-1}$ & 0.035 & 0.280 & \\
\hline $2^{\text {nd }}$ week AFM1 $1^{1}, \mu \mathrm{g} \mathrm{kg}^{-1}$ & 0.055 & 0.320 & \\
\hline $3^{\text {rd }}$ week AFM1 $1^{1}, \mu \mathrm{g} \mathrm{kg}^{-1}$ & 0.045 & 0.320 & \\
\hline $4^{\text {th }}$ week AFM $1^{1}, \mu \mathrm{g} \mathrm{kg}^{-1}$ & 0.030 & 0.360 & \\
\hline
\end{tabular}

\section{CONCLUSION}

The present results support that the hygienic quality of silage is more important than using mycotoxins deactivator for animal performance, even with using low percent of contaminated feed and maintain the level of total aflatoxin and aflatoxin $\mathrm{B}_{1}$ concentration lower than the permissible limits. Feeds naturally contaminated with harmful mycotoxinseven below the FDA limitation (for aflatoxin) in the feed diet canadversely affect the feed intake and nutrients digestibility,rumen fermentation,milk production of dairy cows and increase aflatoxin $\mathrm{M}_{1}$ transferring rate into the milk. 


\section{REFERENCES}

Akande, K.E.;M.M. Abubakar; T.A. Adegbolaand S.E. Bogoro(2006). Nutritional and health implications of mycotoxins in animal feeds: A Review. Pakistan J. of Nutrition, 5: 398-403.

AOAC, (2000). Official Methods of Analysis, 17th ed. Association of Official Analytical Chemists, Washington, DC, USA.

Applebaum, R.S.; R.E. Brackett; D.W. Wiseman and E.H. Marth (1982). Responses of dairy cows to dietary aflatoxin: Feed intake and yields, toxin content and quality of milk of cows treated with pure and impure aflatoxin. J. Dairy Sci., 65:1503-1508.

Auerbach H.; R.F.M. Maas; H.J.M. Op Den Camp; A. Pol and J. Fink-Gremmels (1998). Biodegradation of aflatoxin $\mathrm{B}_{1}$ by bovine rumen microorganisms in vitro and its effects on rumen fermentation, Revue Méd. Vét, 149: 573.

Berthiller F; M. Sulyok; R. Krska; R. Schuhmacher (2007). Chromatographic methods for the simultaneous determination of mycotoxins and their conjugates in cereals. Int. J. Food Microbiol., 119(1-2):33-7.

Bingol, N.T.; P. Tanritanir; S. Dede and E. Ceylan (2007). Influence of aflatoxin present in forages and concentrated feeding stuffs on milk and some serum biochemical parameters in goats. Bull. Vet. Inst. Pulawy, 51:65-69.

Celik, I.; H. Oguz; O. Demet; M.Boydak; H. H. Donmez; E. Sur and F. Nizamlioglu (2000). Embryo toxicity assay of aflatoxin produced by Aspergillusparasiticus NRRL 2999. Brit.Poult. Sci., 41, 401.

Cook, W.O.; J.L. Richard; G.D. Osweiler; D.W. Trampel (986). Clinical and pathologic changes in acute bovine aflatoxicosis: Rumen motility and tissue and fluid concentrations of aflatoxin $\mathrm{B}_{1}$ and $\mathrm{M}_{1}$. Am. J. Vet. Res., 47: 1817-1825.

Diaz, D.E.; W.M. Hagler; J.T. Blackwelder; J.A. Eve; B.A. Hopkins; K.L. Anderson; F.T. Jones and L.W. Whitlow (2004). Aflatoxin binders. II: Reduction of aflatoxin $\mathbf{M}_{1}$ in milk by sequestering agents of cows consuming aflatoxin in feed. Mycopathologia, 157:233-241.

Diekman, M.A. and M.L. Green (1992). Mycotoxins and reproduction in domestic livestock. J. Anim. Sci., 70 (5):1615-1627.

Dumas, B.T. and H.G. Biggs (1972). Standard Methods of Clinical Chemistry. Vol. 7. Academic Press, New York, pp175.

Duncan, D.B. (1955). Multiple ranges and multiple F test. Biometrics, 11: 1-42.

EFSA (European Food Safety Authority) (2004). Opinion of the scientific panel on contaminants in the food chain on a request from the Commission related to aflatoxin B1 as undesirable substance in animal feed. EFSA J., 39:1-27.

FDA (Food and Drug Administration) (2000). Guidance for Industry: Action Levels for Poisonous or Deleterious Substances in Human Food and Animal Feed. Accessed May20,2011. http://www.fda.gov/Food/GuidanceComplianceRegulatoryInformation/GuidanceDocuments/Chemical Contaminants andPesticides/ucm 077969.htm.

Fink-Gremmels, J. and, H.Malekinejad (2007). Biochemical mechanisms and clinical effects associated with exposure to the mycoestrogenzearalenone. Anim. Feed Sci. Technol., 137: 326-341.

Gaines, W.L. (1928). The energy basis of measuring milk yield in dairy cows. I11 Agr. Expt. Sta. Bul. 308: 403-438 Illus.

Galvano, F.; A. Piva; A. Ritieni and G. Galvano(2001). Dietary strategies to counteract the effects of mycotoxins: A review. J Food Prot., 64:120-131.

Henry, M.H. (2006). Mycotoxins in Feeds: CVM's Perspective, Presentation for Risk Management Agency, August 23, 2006, in Austin, http://www.fda.gov/AnimalVeterinary/Products/AnimalFoodFeeds/Contaminants/ucm050974.htm.

Korosteleva, S.N.; T.K. Smith and H.J. Boermans (2007). Effects of feedborneFusariummycotoxins on the performance, metabolism and immunity of dairy cows. J. Dairy Sci., 90: 3867-3873. 
Kutz, R.E.; J.D.Sampson; L.B. Pompeu; D.R. Ledoux; J.N. Spain; M. Vázquez-Añón and G.E. Rottinghaus (2009). Efficacy of Solis, NovasilPlus, and MTB-100 to reduce aflatoxin $\mathrm{M}_{1}$ levels in milk of early to mid lactation dairy cows fed aflatoxin $B_{1}$. J. Dairy Sci., 92: 3959-3963.

May H.D.; Q. Wu andC.K.Blak (2000). Effects of the Fusarium spp. mycotoxinsfusaricacid and deoxynivalenolon The Growth of Ruminococcusalbus and Methanobrevibacterruminantium. Canadian J. of Microbiology, 46: 692699.

McDonald, P.; A.R. Henderson and S.J.E. Heron (1991). The Biochemistry of Silage. Chalcombe Publications, Marlow, Bucks, UK. 111p.

Mertens, D.R and R.D Wyatt (1977). Acute aflatoxicosis in lactating dairy cows. J. Dairy Sci., 60: 153154.

Mojtahedi, M. (2013). Effect of aflatoxin $\mathrm{B}_{1}$ on in vitro rumen microbial fermentation responses using batch culture. Annu. Rev. Res. Biol., 3: 686-693.

Neathery, M.W.; W.H. Moos; R.D. Wyatt; W.J. Miller; R.P. Gentry and L.W. George (1980). Effects of dietary aflatoxin on performance and zinc metabolism in dairy calves. J. Dairy Sci., 63 (5):789-799.

Nikki, K.; G. Henderson; J. Jeyanathan; S. Kittelmann and P.H. Janssen (2011). Isolation of previously uncultured rumen bacteria by dilution to extinction using a new liquid culture medium. J. Microbial. Meth. 84: 52-60.

NRC (2001). Nutrient requirements of dairy cattle.7th ed. (National Academy Press: Washington, DC).

Phillips T.D.; L.F.Kubena; R.B. Harvey; D.R. Taylor and N.D. Heidelbaugh(1988). Hydrated sodium calcium aluminosilicate. A high affinity sorbent foraflatoxin. Poultry Science, 67: 243-247.

Reitman, S. and S. Frankel (1957). Calorimetric method for the determination of serum glutamicoxaloacetic and glutamic-pyruvate transaminase. An. J. Clin. Path., 28: 56.

Rode L.M. (2008). Maintaining a healthy rumen - An overview.' Available at http://www.wcds.afns.ualberta.ca/Proceedings/2000/Chapter10.htm [verified 5 August 2009].

Sabater-Vilar M.; H.Malekinejad; M.H. Selman; M.A. Van Der Doelen and J. Fink-Gremmels(2007). In vitro assessment of adsorbents aiming to prevent deoxynivalenol and zearalenonemycotoxicoses. Mycopathologia, 163: 81-90.

Schell T.C.; M.D.Lindemann; E.T.Kornegay; D.J. Blodgett and J.A. Doerr(1993). Effectiveness of different types of clay for reducing the detrimental effects of aflatoxin-contaminated diets on performance and serum profiles of weanling pigs. J. Anim. Sci., 71: 1226-1231.

Siedlka E.M.; J. Kumirsecka; T. Ossowski; P. Glamowski; M. Golebiowski; J. Gajdus; Z. Kaczynski and P. Stepnowski (2008). Determination of volatile fatty acids in environmental aques samples Polish. J Environ. Stud., 17: 3.

Smith, E.E.; T.D. Phillips; J.A. Ellis; R.B. Harvey; L.F. Kubena; J. Thompson and G. Newton (1994). Dietary hydrated sodium calcium aluminosilicate reduction of aflatoxin $\mathrm{M}_{1}$ residue in dairy goat milk and effects on milk production and components. J. Anim. Sci., 72:677-682.

Snedecor, G.W. and W.C. Cochran (1982). Statistical method (7th Ed), Iowa Univ. Press, Iowa, USA.

Stroud, J.S. (2006). The effect of feed additives on aflatoxin in milk of dairy cows fed aflatoxincontaminated diets. MS Thesis. North Carolina State Univ., Raleigh.

Tapia, M.O.; M.D. Stern; A.L. Soraci; R. Meronuck; W. Olson; S. Gold; R.L. Koski-Hulbert and M.J. Murphy (2005). Patulin producing molds in corn silage and high moisture corn and effects of patulin on fermentation by ruminal microbes in continuous culture. Anim. Feed. Sci.\& Technol., 119:247258.

Van Keulen. J., B.A Young (1977). Evaluation of acid insoluble ash as a natural markers in ruminant digestibility studies. J. Anim. Sci., 44: 282.

Van Soest, P.J.; J.B. Robertson and B.A. Lewis (1991).Methods for dietary fiber, neutral detergent fiber and non-starch polysaccharides in relation to animal nutrition. J. Dairy Sci., 74: 3583-3597.

Veldman, A.; J.A. Meijs; G.J. Borggreve and J.J. Heeres-Van der (1992). Carry-over of aflatoxin from cows food to milk. Anim. Prod., 55:163-168.

Weichselbaun, T.E. (1946). An accurate rapid method for determination of protein in small amounts of blood, serum and plasma. Am. J. Clin. Pathol., 7:40.

Westlake, K.; R.I. Mackie and M.F. Dutton (1989). In vitro metabolism of mycotoxins by bacterial, protozoal and ovine ruminal fluid preparations. Anim. Feed Sci. Technol. 25: 169-178. 
Whitlow L.W. and W.M.Hagler, Jr (2008). Mold and mycotoxin issues in dairy cattle: effects, prevention and treatment.

Available http://www.wcds.ca/proc/2008/Manuscripts/Whitlow\%20and\%20Hagler.pdf.

Whitlow L.W. and W.M.Hagler, Jr (2005). Mycotoxins: a review of dairy concerns. Available at https://www.sdstate.edu/vs/../Whitlow-Mycotoxins- MSRNC-2005.pdf

Woolford, M.K. (1990): The detrimental effects of air on silage. J.Applied Bacteriology, 68: 101-116.

$\mathrm{Wu}$, F. (2006). Economic impact of fumonisin and aflatoxin regulations on global corn and peanut markets. The MycotoxinFactbook. Food \& Feed Topics. Wageningen Academic Publishers, The Netherlands.

Yiannikouris A.; J. François; L.Poughon; C.G.Dussap; G.Bertin, G.Jeminet and J.P. Jouany(2004). Adsorption of Zearalenone by beta-D-glucans in the Saccharomyces cerevisiae cell wall. J. Food Protection, 67: 1195-1200.

Zaghini A.; G.Martelli; P.Roncada; M.Simioli; L. Rizzi(2005). Mannanoligosaccharides and aflatoxin B B $_{1}$ in feed for laying hens: effects on egg quality, aflatoxins $B_{1}$ and $M_{1}$ residues in eggs, and aflatoxin $B_{1}$ levels in liver. Poultry Science, 84: 825-832.

تأثير استخدام مضادات السموم مع سيلاج الذرة الملوث طبيعيا أوغيرالملوث بالسموم الفطريةعلائداء الأبقار الحلابة.

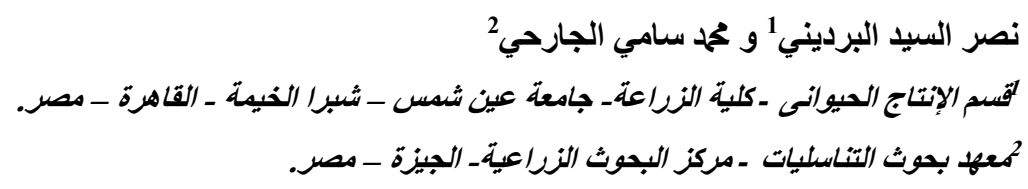

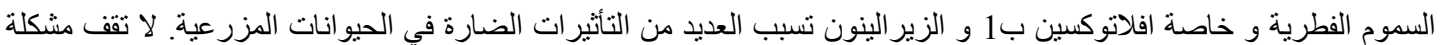

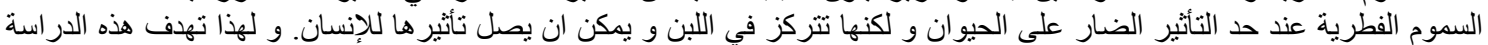

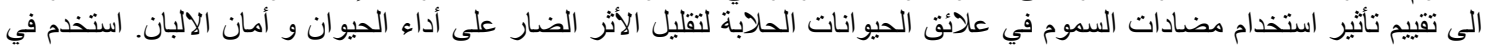

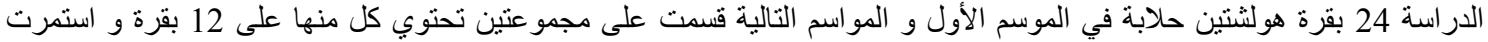

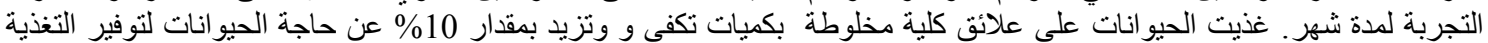

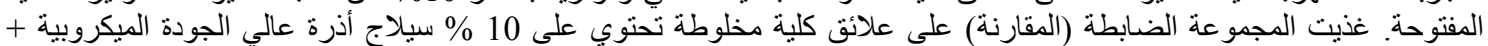

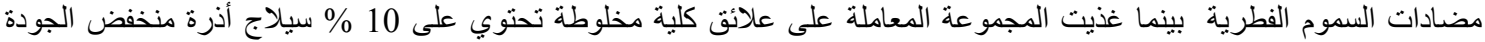

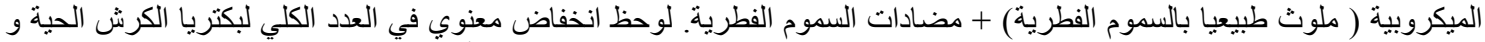

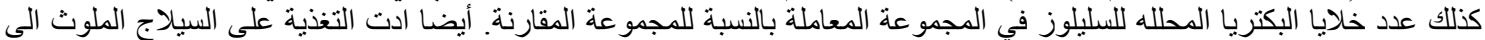

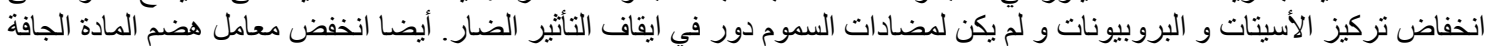

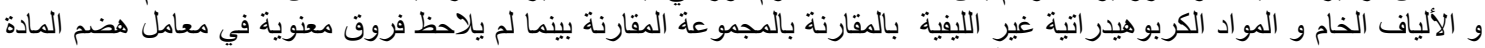

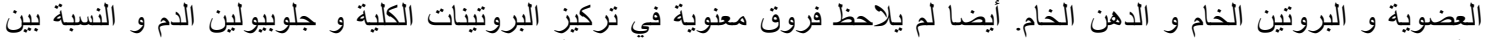

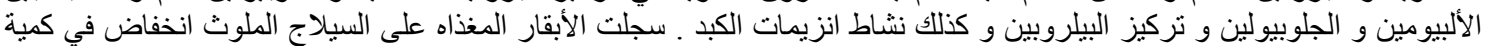

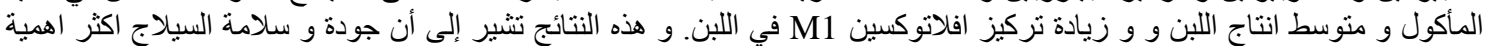

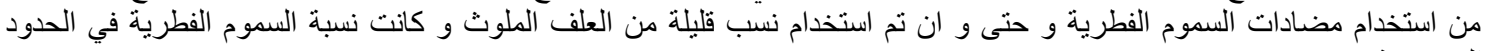

